\title{
"Pemalang pusere Jawa": A City Branding Model in Promoting Tourism Destination of Pemalang Regency, Central Java, Indonesia
}

\section{Riska Rahayu 1,* (1), Achmad Nurmandi 2, (D), Salahudin 3, (D), and Dian Suluh Kusuma Dewi ${ }^{3}$}

${ }^{1}$ Master of Government Science, Jusuf Kalla School of Government, Universitas Muhammadiyah Yogyakarta, 55183, Yogyakarta, Indonesia

2 Department of Political Islam - Political Science, Jusuf Kalla School of Government,

Universitas Muhammadiyah Yogyakarta, 55183, Yogyakarta, Indonesia

${ }^{3}$ Department of Government Science, Faculty of Social and Political Sciences,

Universitas Muhammadiyah Malang, 65144, Malang, Indonesia

4 Department of Government Science, Faculty of Social and Political Sciences,

Universitas Muhammadiyah Ponorogo, 63471, Ponorogo, Indonesia

* Corresponding Author: rskarahayu@gmail.com

\section{ARTICLE INFO}

\section{Publication Info:}

Research Article

How to cite:

Rahayu, R., Nurmandi, A.,

Salahudin, S., E Dewi, D. S. K.

(2020). "Pemalang pusere Jawa":

A City Branding Model in

Promoting Tourism Destination of

Pemalang Regency, Central Java,

Indonesia. Society, 8(2), 325-342.

DOI: $10.33019 /$ society.v8i2.164

Copyright (C) 2020. Owned by Author(s), published by Society

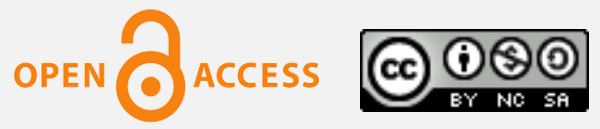

This is an open-access article.

\section{ABSTRACT}

This research aims to analyze the City Branding model "Pemalang pusere Jawa" in Pemalang Regency, which focuses on the strategy of the Government to develop a new brand of Pemalang. "Pemalang pusere Jawa" has shown an impact on increasing tourism in Pemalang, Central Java, Indonesia. The Government supports the success of the City Branding program, and the people involved in the program, stakeholders, and culture, to boost tourism, which will have an impact on the economic sector and increase tourism significantly. Data were analyzed using the Exploratory Data Analysis (EDA) approach in qualitative research that defines and explains distribution characteristics. The data were collected through interviews with six key informants who were selected using a purposive sampling technique. Document studies were also conducted to support data analysis. This research uses the NVivo 12 Plus application to analyze data consisting of Concept Maps, Group Analysis, and Cluster Analysis. There are three points found in this study, consisting of 1) Program; the program is based on Pemalang Regent Regulation Number 27/2017 Article 7 concerning Utilization and Implementation of the City Branding Logo. The branding "Pemalang pusere Jawa" was launched in 2016 and the Visit Pemalang application is used to assist tourists in exploring tourism in

Copyright (C) 2020. Owned by Author(s), published by Society. This is an open-access article under the CC-BY-NC-SA license.

https://doi.org/10.33019/society.v8i2.164 
License: Attribution-

NonCommercial-ShareAlike (CC BY-NC-SA)

Received: March 31, 2020;

Accepted: July 4, 2020;

Published: July 31, 2020;
Pemalang or known as a tour guide application. A Visit Pemalang application makes users easier to find tourism sites in Pemalang Regency by displaying the distance from the users' location to the destination. 2) Partnership; this program is supported by infrastructure stakeholders consisting of the Planalogy Team, the Architect Team, and the Economic Development Expert Team. Program implementation involves the Government and the Community. 3) Culture; various annual events are held as an effort to preserve culture in Pemalang such as "Festival Wong Gunung" and other annual events. Community involvement in the implementation of City Branding is one of the success factors of the program.

Keywords: City Branding; Pusere Jawa; Tourism; Visit Pemalang

\section{Introduction}

The phenomenon of competition between cities with a marketing technique known as City Branding is an effort to form and develop an identity or image of a city, which aims to introduce the city to the public through a slogan or icon that describes the characteristics of the city. According to Ashworth \& Voogd (1994), as cited in Kavaratzis (2004), City Branding is the image of the city as innovative management seeking to improve the coordination of social, economic, commercial, cultural, and government regulations. In research from Khoiroh \& Astuti (2019) describes that community involvement in the City Branding of Pemalang was developing tourism, regional image, economic improvement, and increasing tourist attraction. The application of City Branding is not only focused on creating a logo or slogan, but also must consider the meaning of City Branding which can describe city activities, both community activities, bureaucratic character, and infrastructure that can support the city to make it more well-known. City Branding requires synergy from all elements, including government, city, community, and infrastructure. The Government of Pemalang Regency issued Pemalang Regent Regulation Number 27/2017 concerning the Logo of City Branding Pemalang Regency. The regulation describes the designation of a new logo, with various meanings, as the City Branding logo for the Pemalang Regency. Lack of synergy in the implementation of City Branding will fail the planned goals. The main goal of City Branding is to introduce a city identity (Kavaratzis, 2004).

Several cities in Indonesia have implemented the City Branding model to promote the tourism potential, such as Yogyakarta: "Jogja Istimewa", Solo: "The Spirit of Java", Surabaya: "Sparkling Surabaya", Banyuwangi: “The Sunrise of Java", and Bandung: "Paris Van Java". The mentioned cities above are an example of the cities that uses the City Branding model to promote its tourism at the international level. The number of tourist visits to Central Java and Pemalang in the 2015-2017 periods, both domestic and foreign tourists described in Table 1 as follows: 
Table 1. Data on Domestic and Foreign Tourist Visits to Central Java Province and Pemalang Regency in 2015-2017

\begin{tabular}{ccccc}
\hline Year & \multicolumn{2}{c}{ Central Java } & \multicolumn{2}{c}{ Pemalang } \\
\hline & Foreign & Domestic & Foreign & Domestic \\
$\mathbf{2 0 1 5}$ & 375,166 & $31,432,080$ & 271,000 & 469,477 \\
$\mathbf{2 0 1 6}$ & 579,942 & $36,899,776$ & 387,591 & 573,371 \\
$\mathbf{2 0 1 7}$ & 421,191 & $33,030,843$ & 318,537 & 692,842 \\
\hline
\end{tabular}

Source: Badan Pusat Statistik Kabupaten Pemalang (2017)

Central Java Province, which is one of the provinces in Indonesia, consists of 29 regencies and 6 cities. Central Java Province has implemented the City Branding model. One of the regencies in Central Java Province that has implemented City Branding is Pemalang. Pemalang is located between two regencies that are well known for its trademarks, Pekalongan: "Batik Pekalongan", and Tegal: "Kota Bahari" which has hot spring tourism destinations. Referring to these conditions, Pemalang makes efforts to promote its tourist destinations to make it more well-known.

There are various tourist destinations in Pemalang, starting from beaches, rivers, waterfalls, and there are tourist destinations in mountainous and hilly areas because of the geographical location of Pemalang at the foot of Slamet Mount. Also, there are tourist destinations related to spirituality which is a cultural heritage. Unfortunately, the existing tourism potential has not been maximized. Not many people know the location of tourist destinations in Pemalang because of the lack of tourism promotion by the government. The motto for Pemalang, the first to be used is "Pemalang IKHLAS", which means I: Indah (Beautiful), K: Komunikatif (Communicative), H: Hijau (Green), L: Lancar (Efficient), A: Aman (Safe), and S: Sehat (Healthy). However, the existing tourism potential has not been increased because there is no special tourist attraction, and Pemalang is still a transit route for traveling through the north coast of Java. Therefore, the Pemalang Regent collaborates with the Regional Development Planning and Research Agency of Pemalang Regency, the Tourism, Youth and Sports Office of Pemalang Regency, and community leaders to create a City Branding model to promote and increase tourist destinations in Pemalang. The number of tourists visiting Pemalang in the 2015-2016 periods after implementing City Branding has been described in Table 1.

Previous research related to City Branding, according to Kavaratzis \& Ashworth (2005), City Branding is one of the strategic paths that regions can take in improving the tourism sector. In the research of Setianti et al, (2018) stated that the Denpasar City implementing City Branding is one way to market Denpasar City's new identity as a creative city, which is supported by organizing regular events. This research examines the implementation of City Branding to determine whether the meaning of the slogan has reached the public.

Therefore, this research aims to examine the programs created by the Pemalang Regency Tourism, Youth, and Sports Office through the implementation of the City Branding model which aims to promote and improve tourism in Pemalang, with the slogan "Pemalang pusere Jawa".

\section{Literature Review}

\subsection{From Marketing City to Branding City}

In research from Lynch (2010) defines identification as "the degree to which a person can identify or remember a place as distinct from other places". Accordingly, the identification is a 


\section{"Pemalang pusere Jawa": A City Branding Model in Promoting Tourism Destination of Pemalang Regency, Central Java, Indonesia}

distinction that is, at first sight, apparent and noticeable, as well as sturdy as generating pictures on people's minds even though they have not seen it before. Identity is almost always unique and not reproducible. The growing town has a unique identity consisting of both negative or positive images and memories. The city's picture consists of the view of urban elements, including monumental buildings, public spaces, and other special features. When discussing the image of the city from the perspective of City Branding, it should be noted, first of all, that many cities are now trying to promote themselves through iconic artifacts. In general terms, City Branding is based mainly on three key attributes: image, uniqueness, and authenticity. Almost every city has City Branding on its agenda to redevelop its image (Kavaratzis \& Ashworth, 2007). Branding, primarily based on marketing strategies, is increasingly used for urban marketing and promotion. City Branding involves a significant change of perspective on the entire marketing effort (Kavaratzis, 2004).

Kotler even argues that "places are products of which identities and values must be designed and marketed as products" (Kotler et al., 1999). According to Ashworth, one of the goals of City or Place Branding is to discover or establish individuality that makes the area distinct from others (Ashworth, 2009, p. 9). The key objective in the development of urban brands is to express the city in a globalized world. If a city wants to "work" to be efficient, it requires economic prosperity and an attractive picture. City Branding must, therefore, be concerned with "how culture and history, economic growth and social progress, infrastructure and architecture, landscape and the environment, among other things, can be incorporated into a market identity suitable to all people" (Zhang \& Zhao, 2009, p. 248). Thanks to the rapid change in technology and the transition from a regional to a globalized world, cities are forced to compete with each other to be an enticing tourist destination, a place of work, a vibrant cultural place, and many more (Kotler \& Gertner, 2002). In research from Kavaratzis \& Ashworth (2005, p. 1) argues that increasing competition among cities could be seen as one of the results of globalization evident in different forms and fields of activity. The contemporary city needs to be continually changed. In this context, cities design strategies to help, "sell", and promote them on the global market. A literature survey indicates that there are three major approaches to promoting cities: cultural mega-events, preservation, promotion of architecture, and the construction of the emblematic buildings (Hankinson, 2007, p. 240; Kavaratzis \& Ashworth, 2005, p. 1).

Branding is a means of promoting the area through promotional campaigns, but the word Branding is a means of displaying an operation that has an identity created by the current conditions. City Branding is a technique aiming to create a place that can "speak" or "explain" to the public (Purwianti \& Lukito, 2014; Trabskaia et al., 2019; Yananda \& Salamah, 2014). A single high-profile mega-event cannot successfully meet City Branding goals. The identity of the city, both official propaganda routine and development practices, need to be incorporated. Although the Expo has been hailed as a successful mega-event and has had positive effects on the increase in tourism levels after a while, its long-term impact on City Branding remains to be seen (Wang et al., 2012). City Branding is a method of creating a city or area that can be identified by the target audience as investors, visitors, and a sequence of activities through slogans, logos, symbols in a range of other advertising media. A City Branding campaign is not only about a slogan or a sale, but also must have a clear sense in the form of an image of the situation and the condition. It is about expectations for the city in which seeing or hearing signs, logos, or symbols will remind people of the city (Mueller \& Schade, 2012).

The idea of City Branding is to place the city's logo to capture people's minds, making them want to visit the city. Moreover, Community Branding is also supposed to adopt a style

Copyright (C) 2020. Owned by Author(s), published by Society. This is an open-access article under the CC-BY-NC-SA license. 


\section{"Pemalang pusere Jawa": A City Branding Model in Promoting Tourism Destination of Pemalang Regency, Central Java, Indonesia}

that demonstrates how the community is introduced. According to Larasati \& Nazaruddin (2016) and Zafira (2017), there are some criteria for City Branding. The first is attributes dealing with the form of the emblem or logo as a prerequisite to making the City Branding intended to convey the concept, vision, attractiveness, and personality of the city. The message has an essential role in the establishment of City Branding as a message in the form of tales, history, and other fascinating items that can be unique tourism to visit the city. The second is differentiation concerning the distinction between one city and another as the city will have its uniqueness. The last is an embassy in which stakeholders have the goal of creating a community to come and live in the region.

Group Branding can be interpreted in a three-level engagement framework. The first level refers to the physical and visible aspects that can be seen from an area. The second level is made up of advertising methods used by the city to promote itself. The third level is people's contact with the world through their voices and the media. In the process of Urban Branding, such multi-level communications should be concerned (Derudder et al., 2003; Kavaratzis, 2009; Morgan et al., 2003).

Since the emergence of mass tourism in the 1960s, city tourism has consistently been one of the fastest-growing segments of the travel market in developed countries (Ashworth, 1989; Jansen-Verbeke \& van Rekom, 1996; Law, 2002; Maitland, 2006; Selby, 2004). International transit arrivals worldwide are expected to reach 1.4 million by 2020 and 1.8 billion by 2030 (UNWTO, 2016). Over the period 2007-2014, the number of city trips worldwide increased by 82 percent and reached 22 percent market share of all holidays, according to the latest official statistics (IPK International, 2015, p. 8). Together with a sustained rise in city tourism, cruise tourism has increased by 248 percent, while water, sand, and relaxation holidays have increased by 39 percent, and tours have shown a steady growth rate of 21 percent over the past eight years. All developed and developing economies are experiencing the growth of city tourism through marketing strategies. In 2014 the market share of city holidays was 21\% in Europe, 17\% in North America, 25\% in the Asia Pacific, and 22\% in South America (IPK International, 2015).

Spillane (1991) explains that tourism is a nomadic or temporary travel activity done by individuals or groups. One's interest in tourism aims to balance happiness with both dimension environmental sciences, social, cultural, and natural. Tourism is an activity event, conducted by individuals or groups, whether in the country or abroad. These activities require the ease of services like support. The government is also expected to facilitate these activities to fulfill people's desires (Riza et al., 2012). City Branding is a part of efforts to improve the local culture of a city as a cultural city (Castillo-Villar, 2018; Larasati \& Nazaruddin, 2016). In supporting the promotion of culture, community participation and role, communication, and implementation of the event as media are required to attract attention (Kavaratzis \& Ashworth, 2007; Lucarelli, 2018; Riza et al., 2012). The city has a significant effect on the city's image (Castillo-Villar, 2018; Kavaratzis \& Ashworth, 2005; Shirvani-Dastgerdi \& De-Luca, 2019). The influence of City Branding is also a direct impact on the image of the city and the visit of youth travelers but does not affect the image of the city through the intervening (Kavaratzis \& Hatch, 2013). City Branding is one-factor influencing business opportunities as a result of social and network promotion (Hereźniak, 2017; Purwianti \& Lukito, 2014; Riza et al., 2012). Phase supporting City Branding can be seen from the communication in the planning, implementation, and evaluation (Komninos et al., 2018; Pompe, 2017; Wang et al., 2012). In planning the vision and mission of the program formation, promotions are carried out, and the evaluation phase was done by improving infrastructure.

Copyright (C) 2020. Owned by Author(s), published by Society. This is an open-access article under the CC-BY-NC-SA license. 


\section{"Pemalang pusere Jawa": A City Branding Model in Promoting Tourism Destination of Pemalang Regency, Central Java, Indonesia}

City Branding also implemented in Shanghai. The branding's effort can be traced back to promoting the city as a tourist choice since China has introduced policies of openness and reform. Tourism was first seen as an essential economic sector in the city planning formulated in the early 1990s that could generate direct revenue, increase domestic consumption, create job opportunities, and restructure urban industries (Komninos et al., 2018; Kunzmann, 2004; He \& Zheng, 2011). To turn Shanghai into a first-class metropolis and an enticing tourist destination, tourism was introduced as the main objective of the "11th Five-Year Plan" (2005-2010) and the medium-term tourism development plan (Wang et al., 2011; Wang et al., 2012).

To increase tourism, various measures have been taken. These measures included massive investment in tourism infrastructure, the creation of new tourist spots, the development of various tourist routes connecting the historic civilization of the city with recent modernization, and the formulation of official tourism service standards (Hankinson, 2007; Lu, 2003; Kavaratzis, 2004; Setianti et al., 2018; Zhang \& Zhao, 2009). Taking its undoubted advantage of combining the culture and civilization of capitalism, Shanghai succeeded in attracting increasing numbers of domestic and foreign tourists. Tourism development became a rapidly growing part of the economy of the city, and City Branding was undertaking tourist-oriented advertising. The Shanghai Tourism Festival was a positive promotion of tourism. It has been successfully held every fall since 1996 (Wang et al., 2012). To describe the marketing of the City Branding to increase tourism, according to Larasati \& Nazaruddin (2016) and Zafira (2017), they analyze from several aspects, i.e.: Partnership (Stakeholders and Infrastructure); Program (Product, Packaging, Place, Price, and Promotion); Culture by the people.

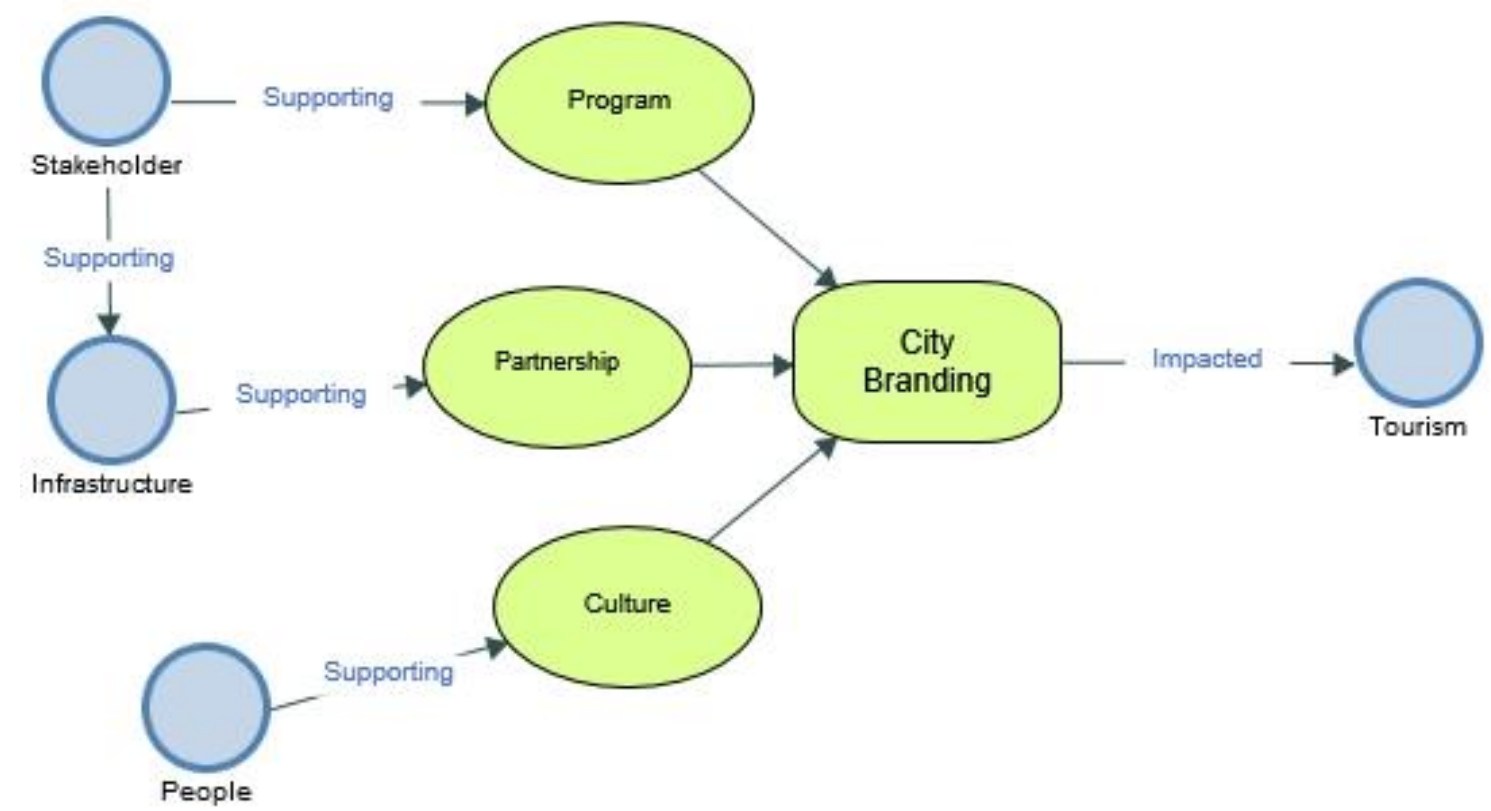

Figure 1. City Branding Concept Map by NVivo 12 Plus Source: Primary Data (2020)

\section{Research Methodology}

This research will discuss the City Branding model as an effort to promote tourism in Pemalang Regency. City Branding implementation in promoting tourism is supported by the government, stakeholders, and the community. This research examines the impacts of City Branding in promoting and improving tourism in the Pemalang Regency. This research uses a qualitative research approach. Using a qualitative research approach with a purposive sampling

Copyright ( ) 2020. Owned by Author(s), published by Society. This is an open-access article under the CC-BY-NC-SA license. 


\section{"Pemalang pusere Jawa": A City Branding Model in Promoting Tourism Destination of Pemalang Regency, Central Java, Indonesia}

method called decision sampling, is a conscious choice of participants based on the attributes possessed by the participants (Etikan, 2016). It is a known strategy that does not involve a basic hypothesis or a fixed number of participants. Data were analyzed using the Exploratory Data Analysis (EDA) approach in qualitative research that defines and explains distribution characteristics. The data were collected through interviews with six key informants who were selected using a purposive sampling technique. Document studies were also conducted to support data analysis. This research uses the NVivo 12 Plus application to analyze data consisting of Concept Maps, Group Analysis, and Cluster Analysis. The following informants were selected are:

a) Head of Development Planning and Research Agency of Pemalang

b) Staff of Tourism, Youth, and Sports Agency Office of Pemalang (Department of Planning and Finance)

c) Development Expert Team

d) Architect Team

e) Planning Team

f) Two Travel Managers

This research adopts Exploratory Data Analysis (EDA) which consists of a description with the criteria or metric features that will be included (Ayyagari, 2012). To obtain the correct data, data processing was carried out with purposive sampling data, namely a random sampling technique where sampling is determined by determining certain characteristics that are following the research objectives so that it is expected to be able to answer research questions (Bloor \& Wood, 2016). This research uses the NVivo 12 plus application to analyze interview data and documentation. The NVivo application is an analytical application of qualitative research data that has been used by many qualitative researchers around the world (Sotiriadou et al., 2014). This application helps researchers visualize and categorize data, interviews, and documentation with Concept Maps, Group Analysis, and Cluster Analysis. Cluster analysis is used to analyze how strong the relationship between one variable is with another variable. Cluster analysis is used to map thoughts in a concept and propositions based on variables and Group analysis is used to see which variable is more dominant to have an interrelation between existing variables.

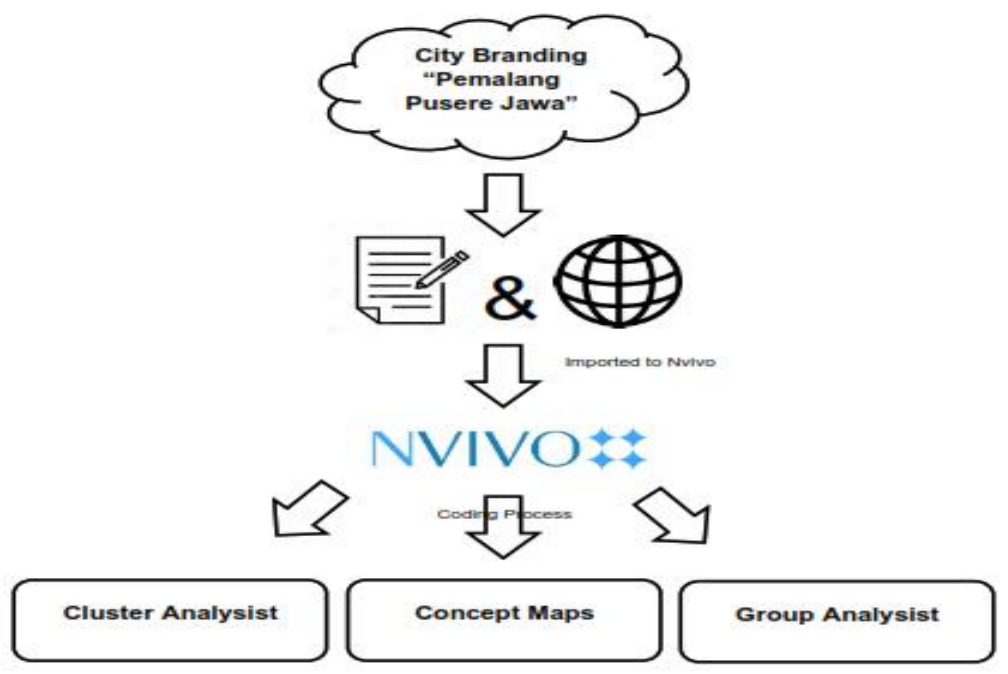

Figure 2. Research Method Structure

Source: Primary Data (2020)

Copyright ( ) 2020. Owned by Author(s), published by Society. This is an open-access article under the CC-BY-NC-SA license. 
Data analysis was carried out starting from the stage of transcribing the interview results into text data that was entered into the NVivo application. The NVivo 12 Plus application will analyze concept maps, group analysis, and cluster analysis with manual coding for some of the contents of the respondents' responses in the interviews that have been conducted. The results of data processing were analyzed and confirmed in several supporting and relevant theories in the City Branding research.

\section{Results and Discussion}

\subsection{The Role of City Branding "Pemalang pusere Jawa" in Promoting and Increasing} Tourism in Pemalang

"Pemalang pusere Jawa" is one of the major programs in promoting and increasing tourism in the Pemalang Regency. Implementation of development programs was carried out quarterly, and then marketing activity conducted biweekly to share updates on the latest developments via social media or websites. Local communities with the support of local governments try to exploit natural resources and make them unique regional products. Based on geographic location, soil structure, and weather, the southern area of Pemalang is suitable for pineapple cultivation. Based on these conditions, the government formulated a City Branding policy. Pemalang Regent has a vision and mission related to City Branding which aims to build and develop Pemalang Regency. Pineapple is a plant that can grow in all seasons. During the dry season or the rainy season, pineapple plants continue to grow in good quality. Following the statement of the Head of Development Planning and Research Agency of Pemalang:

"Pemalang is the main producer of pineapples. The pineapple was chosen as an icon because pineapples are widely cultivated in Pemalang. This icon is used because of the natural resources that are already available and the community is ready and able to increase the economy or business income for the regional economy" (Interview, 2020).

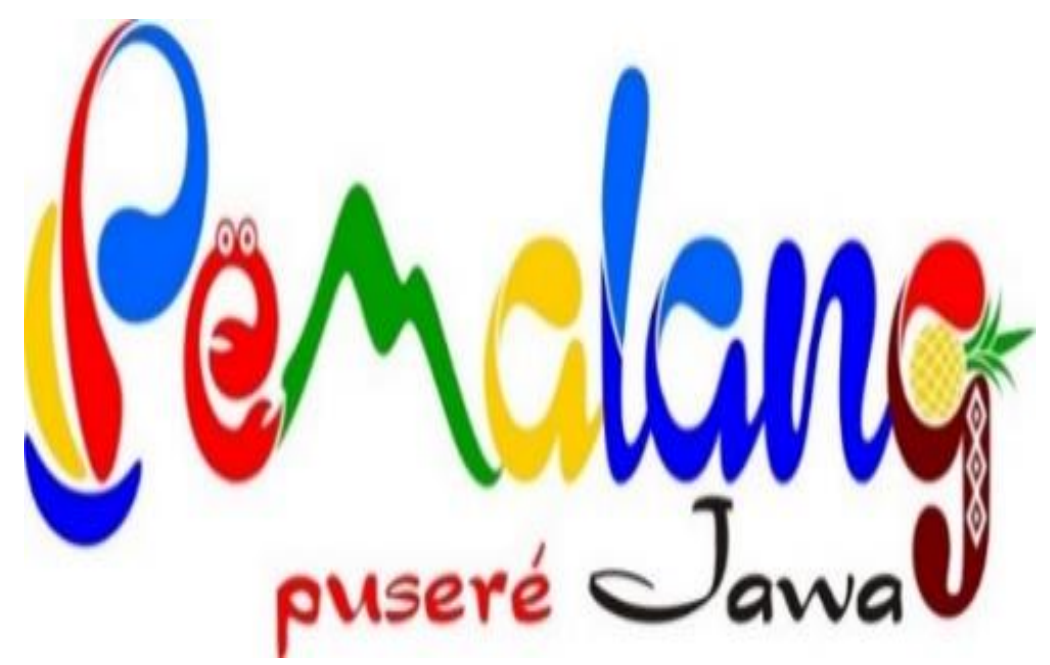

Figure 3. Logo City Branding Pemalang Regency

Source: Pemerintah Kabupaten Pemalang (2017)

"Pemalang pusere Jawa" was launched on 28 December 2016, 29 days before the 442nd Anniversary of Pemalang (Kabarpemalang.com, 2016). The logo is a visual identity that reflects the characteristics, uniqueness, potential, and culture of the Pemalang Regency community which is different from other regions. 


\section{"Pemalang pusere Jawa": A City Branding Model in Promoting Tourism Destination of Pemalang Regency, Central Java, Indonesia}

\subsection{City Branding Program of Pemalang Regency}

In Pemalang Regent Regulation Number 27/2017, it is stated that the City Branding logo consists of 3 elements, namely the logotype, logogram, and tagline. The logotype is formed from the name of the Regency, namely Pemalang. A logogram is formed and the first letter in the word Pemalang is " $\mathrm{p}$ " which represents a picture of a boat, a visual smile, and a picture of water and waves. The tagline is formed from the word "pusere Jawa". The concept of the "Pemalang pusere Jawa" logo has a philosophy and meaning. Overall, in a philosophical context, the "Pemalang pusere Jawa" logo is inspired by water, a natural resource in Pemalang Regency. Water describes the coolness, fertility, calmness, hope, and harmony of the Pemalang Regency which always upholds Javanese culture and can adapt to all conditions. In the context of meaning, the word "Pemalang" in "Pemalang pusere Jawa" logo has several parts that have meaning in each of its parts, which consist of 1) Picture of A Boat, 2) Picture of Hull/Boat Body, 3) Picture of Water and Waves, 4) Picture of Crab, 5) Picture of Pineapple, 6) Picture of Batik Motif. The slogan/tagline "pusere Jawa" means that Pemalang Regency is in the middle (center) between the western tip of Java Island and the eastern tip of Java Island. The hope is that Pemalang Regency can become the center or axis of the new development area in Java (Pemerintah Kabupaten Pemalang, 2017).

Picture of A Boat in the letter "p": It depicts democratic leadership does not only rely on the leader alone but also requires the participation of all levels of the community in development to create a good and harmonious relationship between leaders and the community, to achieve goals. Besides, the boat depicts the characteristics of coastal communities and the marine wealth of the North Coast of Java Island which has the potential for beautiful beaches. Picture of the Hull/Boat Body is also interpreted as a visual smile: It depicts the friendliness, sincerity, and loyalty shown by the leaders, the community, and nature in Pemalang Regency as the basic capital in government, the community, and development activities. Picture of Water and Waves; Water: It depicts a fighting spirit and boundless loyalty that continues to flow continuously from leaders who always provide services to the community and people who are active and engaged in development activities towards endless achievement. Waves: It depicts the identity of the resources owned by the Pemalang Regency. Picture of Crab in the letter " $\mathbf{e}$ ": It depicts Soka crab cultivation is one of the potential economic sources of the Minapolitan community in Petarukan and Ulujami districts, Pemalang regency. Soka crab cultivation is also able to penetrate the national market and is one of Indonesia's export commodities (Pemerintah Kabupaten Pemalang, 2017).

Besides, the letter " $m$ " means mountain: Pemalang Regency has a mountainous area in the form of Slamet Mount, which is the highest mountain in Central Java. The letter "a": It depicts the typical snacks of Pemalang Regency, Ogel-Ogel. Picture of the Pineapple: Honey Pineapple is one of Pemalang Regency's flagship fruits and loved by the wider community, both inside and outside the region, and can compete in traditional and modern markets. The five leaves mean the basic principles of sustainable development. The five principles include 1) Ecology, 2) Economics, 3) Equity, 4) Engagement, and 5) Energy. The letter "g": It depicts the initials of some typical foods and products of Pemalang Regency including Grombyang. Grombyang rice dish is soupy and similar to Soto. Besides Grombyang, a typical product of the Pemalang Regency with the initial " $\mathrm{g}$ " is a sarong Goyor. Picture of Batik Motif: It depicts that Pemalang Regency has a typical dance, namely Pemalang Selendang Dance (Tari Selendang Pemalang or TSL). Some of the batik motifs have the meaning of the movements of the Pemalang Selendang Dance, which are a combination of movements from several regions (Pemerintah Kabupaten Pemalang, 2017).

Copyright (C) 2020. Owned by Author(s), published by Society. This is an open-access article under the CC-BY-NC-SA license. 


\section{"Pemalang pusere Jawa": A City Branding Model in Promoting Tourism Destination}

of Pemalang Regency, Central Java, Indonesia

The logo used by all levels of government Pemalang aims to promote and build a positive image of Pemalang through official government activities, the use of merchandising and printing products, dissemination activities to the community/auxiliary organizations and other networking (SME products), and promotional activities or other means of socialization. There are typical pineapples processed products such as pineapple jam, syrup, chips, and Goyor fabric. This product will be distributed to souvenir shops in Pemalang. Even though it is a simple processed product, it has an impact on the people's economy and reduces unemployment. It is one form of City Branding implementation in terms of products made by the Pemalang Government. Goyor fabric is Pemalang's mainstay product. The name of Goyor is based on the production process where before the yarn is knitted, it must first be tied up that the design and color match the desired pattern. The flower pattern or image used is beamed Tetris blocks. This holster also has its flexibility and is untangled that people call it a Goyor. Data in 2018 shows the following Goyor weaving production:

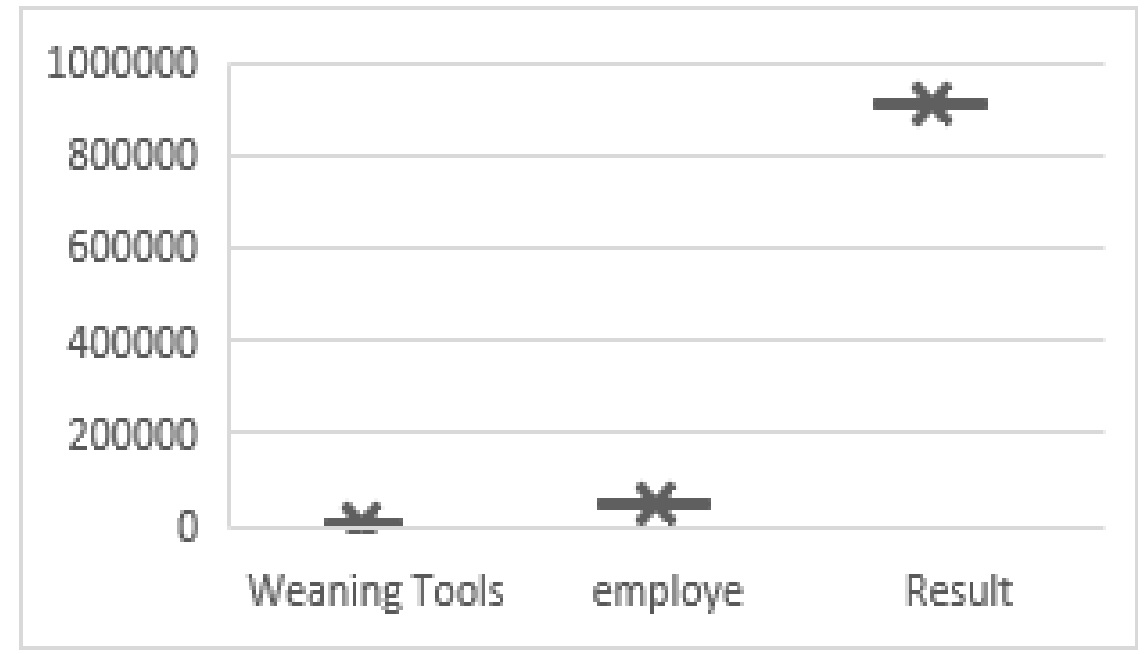

Figure 4. Data on Goyor Weaving Production

Source: Dinas Pariwisata, Pemuda, dan Olahraga Kabupaten Pemalang (2018)

Figure 4 shows that the production of Goyor fabric in Pemalang was \pm 915,750 PCs/year with 50.875 workers. Traditional looms used in the production process amounted to 2,035 units. Consumers consider that the Goyor Weaving is a perfect type of fabric considering the traditional weaving system and adding its selling points for people visiting Pemalang, as explained by a consumer:

"Visiting Pemalang, if you don't buy Goyor, it means you haven't visited Pemalang. The weaving is of excellent quality and durable fiber!" (Interview, 2020).

The Pemalang Regency Government has designed a City Branding program by increasing travel destinations in Pemalang, particularly in the hill and coastal in southern Pemalang areas. The government considered this program to be superior and able to increase tourist visits to Pemalang. It is consistent with one of the interview statements with the Tourism, Youth, and Sports Agency Office of Pemalang (Department of Planning and Finance):

"The program was not formed in part, but from the beginning, the Regent was elected, who had a vision and mission to form the "Pemalang pusere Jawa" brand and planned 


\title{
"Pemalang pusere Jawa": A City Branding Model in Promoting Tourism Destination of Pemalang Regency, Central Java, Indonesia
}

\begin{abstract}
a program to develop superior tourism sites in South Pemalang. Then proceed with tourism development and marketing through the exhibition and the Visit Pemalang application" (Interview, 2020).
\end{abstract}

Based on the statement above, the Visit Pemalang application can ease users in finding tourism sites in Pemalang Regency by displaying the distance from the users' location to the destination. It is accompanied by a video preview as an essential feature to describe tourism sites in Pemalang. This term is corresponding to the context of tourism. Smart technologies change consumer experiences and generate creative tourism business models. Cloud computing, big data, mobile apps, location-based services, geo-tag services, sound technology, virtual reality, augmented reality, and social networking services are all cutting-edge examples of smart technologies enhancing the tourism experiences and services (Wang et al., 2012).

\subsection{The Partnership of Pemalang City Branding}

A program will not run without the support and cooperation of the various parties. In the partnership system, there are three essential pillars, which are crucial in the development of tourism destinations, namely the government, private parties or investors, and the community. The role of the regional government in this regard must be able to act as a regulator and facilitator. In that sense, the government as a regulator should be able to make rules or policies that can build an optimal development of the region. Moreover, as the facilitator, the regional government is expected to provide guidance and training to the community to be able to become professional resources ready to become perpetrators of direct tourism services.

Table 2. The Value of the Partnership Group Analysis by NVivo

\begin{tabular}{ccc}
\hline Subject & \multicolumn{2}{c}{ Partnership } \\
\cline { 2 - 3 } Government & Infrastructure & Stakeholder \\
People & $73.31 \%$ & $50 \%$ \\
Amount & $26.69 \%$ & $50 \%$ \\
\hline
\end{tabular}

Source: Primary Data (2020)

From Table 2 above, it can be seen that the dominant network in seeing the partnership was formed in the process of implementing programs and infrastructure. The infrastructure stakeholders involved were the Planalogy Team, Architect Team, and the Economic Development Expert Team. The program implementation also involved both the government and the community. Figure coding value above shows the relationship between the factors supporting the City Branding with the various actors involved. While the government was actively engaged in the process of implementing materials and infrastructure by $73,31 \%$ to hold the infrastructure sector, and the community around the tourist areas have carried out tourism management activities that have been supported and optimized by the Pemalang Regional Government by $26,69 \%$. The stakeholder also supported the City Branding program by taking a role in establishing a cooperative relationship with the government as $50 \%$ connectivity to Government and $50 \%$ of people. Implementation of the program, especially in the management of existing tourism sites in Pemalang, was conducted by the government and its staff in collaboration with the villages in the management and development of tourism sites. The following is the Pemalang tourism data: 


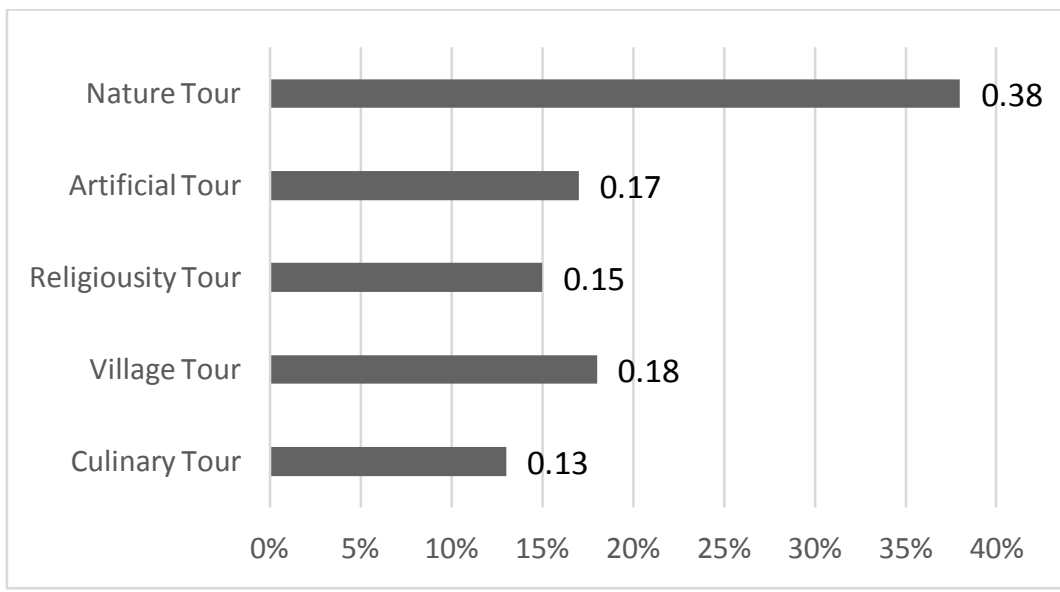

Figure 5. Tourism in Pemalang

Source: Dinas Pariwisata, Pemuda, dan Olahraga Kabupaten Pemalang (2017)

Figure 5 explains that in 2017, the most visited tourism sites in Pemalang were nature tourism by 38 percent. There are 27 nature tourism objects in Pemalang Regency. The village tour followed it, and the least visited one was the culinary tour. The number of nature tourism visits in the Pemalang Regency was inseparable from the City Branding program. A similar case also happened in Beijing in which the existence of City Branding was one of the strategies to promote what was owned by the region as part of the reconstruction of regional development in supporting the economic system. The City Branding strategy, as the process of establishing an area that can be recognized by the public, it was not only based on the slogan or icon only. However, it must have the personality or characteristics of the people reflected in the culture of the city (Zhang \& Zhao, 2009).

\subsection{Culture of Pemalang toward City Branding}

The personality characteristics of the Pemalang Regency community were generally the same as other regions, namely being friendly and still preserving the culture. Cultural values influence to attract tourists to visit an area, as can be seen in the following table:

Table 3. Correlation Variable of Culture

\begin{tabular}{cc}
\hline Variable & Pearson Coefficient \\
\hline Government-Culture & 0,85 \\
People-Culture & 0,49 \\
Program-Culture & 0,46 \\
\hline
\end{tabular}

Source: Primary Data (2020)

Table 3 above shows that the cultural issues in the City Branding have been correlated with another variable supported behind. The culture of Pemalang supported by the Government significantly ranged from 0.85. This figure is almost perfect in the standard of Pearson Correlation Coefficient, meaning that in the aspect of a culture in Pemalang, it has outstanding support of the government in the City Branding process. Culture preservation in Pemalang was carried out annually, such as the "Festival Wong Gunung" and other events. Community involvement in the implementation of City Branding became one of the factors. People were required to preserve the culture owned as a form of cultural identity-area course with the support of the regional government. The matrix above also shows the public enthusiasm for 
City Branding. Six public responses were supporting the presence of City Branding in Pemalang. From these statements, it was expected that the public would agree with the City Branding as it could improve tourism in Pemalang. According to Purwianti \& Lukito (2014), City Branding is one-factor influencing business opportunities as a result of social and network promotion to improve the economy. Moreover, the government budget spent on program enhancement was quite a lot.

The branding effect of culture or entertainment and generally branding on the social mosaic of cities was a final but an essential consideration. The effect of culture is in the form of community involvement/contribution in organizing several events organized by the government to increase credibility between the government and the community. Mommas suggest that the tourism and popularity of City Branding were not explained by economic functionality alone. It was also crucial for its socio-cultural effect. Brands derived their City Branding through culture and entertainment to six tourism sites, primarily from the fact that they transformed the multiform truth around us to a specific order or coherence. Brands eased us to "read" each other and our places and goods climate. Branding was not merely an economic activity inspired by market considerations in this respect (Han et al., 2018; Kavaratzis, 2004; Kunzmann, 2004). Branding is a tactical answer to the uniqueness issue in an increasingly generic and even trivialized environment (Kavaratzis \& Ashworth, 2007; Zukin, 2002). In conclusion, marketing and branding must positively promote cultural development in the regions and cities, and at the same time, social growth and community leisure and entertainment management must be organized and harmoniously reinforcing the city's name (Kunzmann, 2004).

\subsection{The Impact of "Pemalang pusere Jawa" City Branding on Tourism}

Table 4. Budget Pemalang Tourism Improvement

\begin{tabular}{lc}
\hline \multicolumn{1}{c}{ Strategic Output } & Output (\%) \\
\hline Improving the quality of regional development planning and & $8.76 \%$ \\
government performance & \\
Development of nature tourism potential & $\mathbf{8 3 . 9 8 \%}$ \\
Involvement of youth organizations and the program activities & $3.40 \%$ \\
Sport program & $3.87 \%$ \\
Total & $\mathbf{1 0 0 \%}$ \\
\hline
\end{tabular}

Source: Dinas Pariwisata, Pemuda, dan Olahraga Kabupaten Pemalang (2018)

Table 4 indicates that the budgeted strategy of Rp34,114,702,500 shows a significant output figure in tourism development as much as 83.98 percent of the four planned programs. The program includes improving the quality of regional development planning and reporting performance, as well as developing tourism potential, especially in nature tourism. That is Pemalang set the levy for travel is appropriate and can be reached by tourist visitors. The data also show a significant rise in tourist visits in Pemalang for their City Branding. Such a statement of informant following:

"There are several very significant tourist arrivals after the City Branding program.

The revenue from tourists visiting the region is also significant. Therefore, it is expected to increase our revenue from the program implemented" (Interview, 2020). 


\section{"Pemalang pusere Jawa": A City Branding Model in Promoting Tourism Destination of Pemalang Regency, Central Java, Indonesia}

From these statements, it is understood that the increase in tourism was increasingly optimal with the presence of City Branding powered by the government in various ways, like those mentioned above. This also stated by Cohen (1972) clarified that tourists are based on the area to be visited, as well as the level of organization of their tour. On this basis, Cohen distinguishes the growth of tourists on four elements, 1) Drifter, tourists who want to visit areas that they do not know of, and travel in small numbers. 2) Explorer, which is a traveler who travels by arranging his trip, and does not want to follow the usual tourist streets but look for things that are not public. Tourists like this are willing to take advantage of facilities with local standards, and the level of interaction with local people is also high. 3) Individual-Mass Tourist, i.e. tourists who submit their travel arrangements to travel agents, and visit well-known tourist destinations. 4) Organized-Mass Tourist, tourists who only want to visit tourist destinations that are already known, with facilities such as those that can be found in their homes, and their trips (Cohen, 1988).

The success of a significant increase in tourism occurred in January 2018 and peaked in July 2018. The implementation must have been adjusted to the regional budget. The success of the City Branding program also required good cooperation from all sections involved in the program.

\section{Conclusion}

"Pemalang pusere Jawa" City Branding is a step to promote and increase tourism. The strategy used by stakeholders, people, programs, culture, and infrastructure, has been said to be quite successful. However, there are still several issues that have not been successful. The City Branding programs powered by the government must be superior to increase tourism in Pemalang. The government has optimistic about several opportunities and strengths owned by Pemalang. The opportunities in Pemalang are the desire of the community to promote the city with several natural resources. This is also a strength that has been supported by the government in implementing the City Branding program. However, on the other hand, there are also underlying challenges and weaknesses. The challenge faced by the Pemalang government is that it must intensely promote with various collaborations with travel agents or other promotional media. This is also one of the weaknesses of the City Branding program on how to promote and cooperate in its implementation. Then, from this process, the government can see that the program is superior and able to increase tourist visits to Pemalang. The City Branding can boost tourism in Pemalang, thereby it can increase the economy of the people in this regency. The government budget spent on program improvement is ineffective, and it has been proven from the very significant in tourist arrivals after the implementation of the City Branding program. The Revenue from the tourist who visits the region is also significant. Hence, it is expected to increase the revenue of the Pemalang Regional Government.

\section{Acknowledgment}

The authors are grateful to express gratitude to all of those who have had the pleasure to work during this research conducted.

\section{Declaration of Conflicting Interests}

The authors have declared no potential conflicts of interest concerning the research, authorship, and/or publication of this article. 


\section{"Pemalang pusere Jawa": A City Branding Model in Promoting Tourism Destination of Pemalang Regency, Central Java, Indonesia}

\section{References}

Ashworth, G. (1989). Urban tourism: an imbalance in attention. In C. Cooper (Ed.), Progress in Tourism Recreation and Hospitality Management (pp. 33-54). London, United Kingdom: Belhaven Press.

Ashworth, G. (2009). The instruments of place branding: how is it done?. European Spatial Research and Policy, 16(1), 9-22. https://doi.org/10.2478/v10105-009-0001-9

Ayyagari, R. (2012). An Exploratory Analysis of Data Breaches from 2005-2011: Trends and Insights. Journal of Information Privacy and Security, 8(2), 33-56. https:/ / doi.org/10.1080/15536548.2012.10845654

Badan Pusat Statistik Kabupaten Pemalang. (2017). Perkembangan Pariwisata Jawa Tengah Bulan Maret 2017. Retrieved from

https:/ / pemalangkab.bps.go.id/pressrelease/2017/05/02/63/perkembangan-pariwisatajawa-tengah-bulan-maret-2017.html

Bloor, M. \& Wood, F. (2006). Purposive sampling. In Bloor, M., \& Wood, F. Keywords in qualitative methods (pp. 143-143). London: SAGE Publications Ltd. https://doi.org/10.4135/9781849209403

Castillo-Villar, F. R. (2018). City branding and the theory of social representation. Bitácora Urbano Territorial, 28(1), 33-38. https:/ / doi.org/10.15446/bitacora.v28n1.52939

Cohen, E. (1972). Toward A Sociology of International Tourism. Social Research, 39(1), 164-182. Retrieved from http:/ / www.jstor.org/stable/40970087

Cohen, E. (1988). Authenticity and Commoditization in Tourism. Annals of Tourism Research, 15(3), 371-386. https:/ / doi.org/10.1016/0160-7383(88)90028-X

Derudder, B., Taylor, P. J., Witlox, F., \& Catalano, G. (2003). Hierarchical Tendencies and Regional Patterns in the World City Network: A Global Urban Analysis of 234 Cities. Regional Studies: The Journal of the Regional Studies Association, 37(9), 875-886. https:// doi.org/10.1080/0034340032000143887

Dinas Pariwisata dan Olahraga Kabupaten Pemalang. (2017). Laporan Kinerja Instansi Pemerintahan (LKJIP) Dinas Pariwisata dan Olahraga Kabupaten Pemalang Tahun 2017. Retrieved from https://disparpora.pemalangkab.go.id/wpcontent/uploads/2018/11/LKjIP-Pariwisata-2017.pdf

Dinas Pariwisata dan Olahraga Kabupaten Pemalang. (2018). Laporan Kinerja Instansi Pemerintahan (LKjIP) Dinas Pariwisata dan Olahraga Kabupaten Pemalang Tahun 2018. Retrieved from https://disparpora.pemalangkab.go.id/wpcontent/uploads/2019/03/LKJIP-DISPARPORA-TAHUN-2018.pdf

Etikan, I. (2016). Comparison of Convenience Sampling and Purposive Sampling. American Journal of Theoretical and Applied Statistics, 5(1), 1-4. https://doi.org/10.11648/j.ajtas.20160501.11

Han, M., de Jong, M., Cui, Z., Xu, L., Lu, H., \& Sun, B. (2018). City Branding in China's Northeastern Region: How Do Cities Reposition Themselves When Facing Industrial Decline and Ecological Modernization? Sustainability, 10(2), 102. https:// doi.org/10.3390/su10010102

Hankinson, G. (2007). The management of destination brands: Five guiding principles based on recent developments in corporate branding theory. Journal of Brand Management, 14(3), 240-254. https://doi.org/10.1057/palgrave.bm.2550065

Hereźniak, M. (2017). Place Branding and Citizen Involvement: Participatory Approach to Building and Managing City Brands. International Studies. Interdisciplinary Political and Cultural Journal, 19(1), 129-141. https:/ / doi.org/10.1515/ipcj-2017-0008 


\section{"Pemalang pusere Jawa": A City Branding Model in Promoting Tourism Destination of Pemalang Regency, Central Java, Indonesia}

He, L. H., \& Zheng, X. G. (2011). Empirical analysis on the relationship between tourism development and economic growth in Sichuan. Journal of Agricultural Science, 3(1), 212-217. https://doi.org/10.5539/jas.v3n1p212

IPK International. (2015). ITB World Travel Trends Report 2015/2016. Messe Berlin GmbH. Retrieved from http://www.itbberlin.de/media/itb/itb_dl_all/itb_presse_all/WTTR_ITB2016_8_Web.pdf

Jansen-Verbeke, M., \& van Rekom, J. (1996). Scanning museum visitors. Annals of Tourism Research, 23(2), 364-375. https:/ / doi.org/10.1016/0160-7383(95)00076-3

Kabarpemalang.com. (2016, December 28). Pemalang pusere Jawa, City Branding Itu. Retrieved from http://www.kabarpemalang.com/2016/12/pemalang-pusere-jawa-city-brandingitu.html

Kavaratzis, M. (2004). From city marketing to city branding: Towards a theoretical framework for developing city brands. Place Branding, 1(1), 58-73. https://doi.org/10.1057/palgrave.pb.5990005

Kavaratzis, M. (2009). Cities and their brands: Lessons from corporate branding. Place Branding and Public Diplomacy, 5(1), 26-37. https:/ / doi.org/10.1057/pb.2008.3

Kavaratzis, M., \& Ashworth, G. J. (2005). City Branding: An Effective Assertion of Identity or A Transitory Marketing Trick? Tijdschrift voor Economische en Sociale Geografie, 96(5), 506-514. https://doi.org/10.1111/j.1467-9663.2005.00482.x

Kavaratzis, M., \& Ashworth, G. J. (2007). Partners in coffeeshops, canals and commerce: Marketing the city of Amsterdam. Cities, 24(1), 16-25. https:/ / doi.org/10.1016/j.cities.2006.08.007

Kavaratzis, M., \& Hatch, M. J. (2013). The dynamics of place brands. Marketing Theory, 13(1), 6986. https://doi.org/10.1177/1470593112467268

Khoiroh, S. F., \& Astuti, P. (2019). Analisis Partisipasi Masyarakat dalam Pengembangan City Branding di Kabupaten Pemalang Jawa Tengah melalui Pengembangan Pariwisata. Journal of Politic and Government Studies, 8(04), 291-300. Retrieved from https://ejournal3.undip.ac.id/index.php/jpgs/article/view/25058

Komninos, N., Kakderi, C., Panori, A., \& Tsarchopoulos, P. (2018). Smart City Planning from an Evolutionary Perspective. Journal of Urban Technology, 26(2), 3-20. https:/ / doi.org/10.1080/10630732.2018.1485368

Kotler, P., Bowen, J. T. \& Makens, J. C. (1999). Marketing for hospitality and tourism. (2nd ed.). Upper Saddle River: Prentice-Hall.

Kotler, P., \& Gertner, D. (2002). Country as brand, product, and beyond: A place marketing and brand management perspective. Journal of Brand Management, 9(4), 249-261. https://doi.org/10.1057/palgrave.bm.2540076

Kunzmann, K. (2004). Culture, Creativity and Spatial Planning. The Town Planning Review, 75(4), 383-404. Retrieved from http://www.jstor.org/stable/40112620

Larasati, D., \& Nazaruddin, M. (2016). Potensi wisata dalam pembentukan city branding Kota $\begin{array}{llll}\text { Pekanbaru. Jurnal } & \text { komunikasi, }\end{array}$ https://doi.org/10.20885/komunikasi.vol10.iss2.art1

Law, C. M. (2002). Urban tourism: The visitor economy and the growth of large cities. London, United Kingdom: Continuum.

Lu, X. (2003). Shanghai tourism festival and its effects upon the development of the whole tourism industry. Tourism Science, 14(3), 39-42.

Lucarelli, A. (2018). Place branding as urban policy: the (im)political place branding. Cities, 80, 12-21. https://doi.org/10.1016/j.cities.2017.08.004

Copyright (C) 2020. Owned by Author(s), published by Society. This is an open-access article under the CC-BY-NC-SA license. 


\section{"Pemalang pusere Jawa": A City Branding Model in Promoting Tourism Destination of Pemalang Regency, Central Java, Indonesia}

Lynch, K. (2010). The image of the city. Cambridge, Mass: MIT Press.

Maitland, R. (2006). How can we manage the tourist-historic city? Tourism strategy in Cambridge, UK, 1978-2003. Tourism Management, 27(6), 1262-1273. https:// doi.org/10.1016/j.tourman.2005.06.006

Morgan, N., Pritchard, A., \& Pride, R. (2003). Destination Branding: Creating the Unique Destination Proposition. Oxford: Butterworth-Heinemann.

Mueller, A., \& Schade, M. (2012). Symbols and place identity: A semiotic approach to internal place branding-case study Bremen (Germany). Journal of Place Management and Development, 5(1), 81-92. https:// doi.org/10.1108/17538331211209068

Pemerintah Kabupaten Pemalang. (2017). Peraturan Bupati Pemalang Nomor 27 Tahun 2017 Tentang Logo City Branding Kabupaten Pemalang. Berita Daerah Kabupaten Pemalang $\begin{array}{lllll}\text { Tahun } & 2017 & \text { Nomor } & 27 . & \text { Retrieved }\end{array}$ https:/ /jdih.pemalangkab.go.id/uploads/42a851974d5449be9977b7e797db8f1d.pdf

Pompe, A. (2017). City brand in the eyes of values. Advances in Business-Related Scientific Research Journal, 8(1), 9-22. Retrieved from http://www.absrc.org/wpcontent/uploads/2017/06/PAPER-Pompe.pdf

Purwianti, L., \& Lukito, Y. R. D. (2014). Analisis Pengaruh City Branding Kota Batam Terhadap Brand Attitude (Studi kasus pada stakeholder di Kota Batam). Jurnal Manajemen Maranatha, 14(1), 61-80. Retrieved from https://journal.maranatha.edu/index.php/jmm/article/view/73

Riza, M., Doratli, N., \& Fasli, M. (2012). City Branding and Identity. Procedia - Social and Behavioral Sciences, 35, 293-300. https://doi.org/10.1016/j.sbspro.2012.02.091

Selby, M. (2004). Consuming the city: conceptualizing and researching urban tourist $\begin{array}{llll}\text { knowledge. Tourism } \quad \text { Geographies, } & \text { 186-207. }\end{array}$ https://doi.org/10.1080/1461668042000208426

Setianti, Y., Dida, S., \& Putri, N. P. C. U. (2018). City Branding of Denpasar City as a Creative City Through the Denpasar Festival Event. Proceedings of Malikussaleh International Conference on Multidisciplinary Studies (MICoMS 2017), 367-371. Lhokseumawe, Indonesia: Emerald Publishing Limited. https:/ / doi.org/10.1108/978-1-78756-793-1-00025

Shirvani-Dastgerdi, A., \& De-Luca, G. (2019). Boosting city image for creation of a certain city brand. Geographica Pannonica, 23(1), 23-31. https://doi.org/10.5937/gp23-20141

Sotiriadou, P., Brouwers, J., \& Le, T. A. (2014). Choosing a qualitative data analysis tool: a comparison of NVivo and Leximancer. Annals of Leisure Research, 17(2), 218-234. https:/ / doi.org/10.1080/11745398.2014.902292

Spillane, J. J. (1991). Ekonomi Pariwisata: Sejarah dan Prospeknya. Yogyakarta: Kanisius.

Trabskaia, I., Shuliateva, I., Abushena, R., Gordin, V., \& Dedova, M. (2019). City branding and museum souvenirs: towards improving the St. Petersburg city brand. Journal of Place Management and Development, 12(4), 529-544. https:// doi.org/10.1108/jpmd-06-2017-0049

UNWTO. (2016). Tourism Highlight 2016 Edition. World Tourism Organisation UNWTO. Retrieved from https://www.e-unwto.org/doi/pdf/10.18111/9789284418145

Wang, D., Park, S., \& Fesenmaier, D. R. (2011). The Role of Smartphones in Mediating the Touristic Experience. Journal of Travel Research, 51(4), 371-387. https://doi.org/10.1177/0047287511426341

Wang, H., Xiaokaiti, M., Zhou, Y., Yang, Y., Liu, Y., \& Zhao, R. (2012). Mega-events and city branding: A case study of Shanghai World Expo 2010. Journal of US-China Public Administration, 9(11), 1283-1293. Retrieved from http://www.davidpublisher.org/index.php/Home/Article/index?id=9418.html

Copyright (C) 2020. Owned by Author(s), published by Society. This is an open-access article under the CC-BY-NC-SA license. https://doi.org/10.33019/society.v8i2.164 
Yananda, M. R., \& Salamah, U. (2014). Branding Tempat: Membangun Lota, Kabupaten, dan Provinsi Berbasis Identitas. Jakarta: Makna Informasi.

Zafira, R. A. M. (2017). Strategi Komunikasi City Branding Pemerintah Kota Tanjungpinang melalui Slogan "Kota Gurindam Negeri Pantun" Periode 2013-2016 (Undergraduate Thesis). Universitas Muham madiyah Yogyakarta. Retrieved from http:/ / repository.umy.ac.id/handle/123456789/12224

Zhang, L., \& Zhao, S. X. (2009). City branding and the Olympic effect: A case study of Beijing. Cities, 26(5), 245-254. https:/ / doi.org/10.1016/j.cities.2009.05.002

Zukin, S. (2002). Re-imagining Downtown: Problems of Branding the Particular. In Spatial Planning Department, Ministry of the Environment (Ed.), European Cities in a Global Era: Urban Identities and Regional Development-Messages and Conclusions (pp. 10-19). Copenhagen, Denmark: The Ministry of Environment.

\section{About the Authors}

1. Riska Rahayu, a graduate student at Master of Government Science, Jusuf Kalla School of Government, Universitas Muhammadiyah Yogyakarta, Indonesia.

E-Mail: rskarahayu@gmail.com

2. Achmad Nurmandi, obtained his Doctoral degree from Universitas Indonesia, in 2008. The author is a Professor at the Department of Political Islam - Political Science, Jusuf Kalla School of Government, Universitas Muhammadiyah Yogyakarta, Indonesia.

E-Mail: nurmandi_achmad@umy.ac.id

3. Salahudin, obtained his Magister degree from Khon Kaen University, Thailand, in 2017. The author is an Assistant Professor at the Department of Government Science, Faculty of Social and Political Sciences, Universitas Muhammadiyah Malang, Indonesia.

E-Mail: salahudinmsi@umm.ac.id

4. Dian Suluh Kusuma Dewi, obtained her Magister degree from Universitas Brawijaya, Indonesia, in 2008. The author is an Assistant Professor at the Department of Government Science, Faculty of Social and Political Sciences, Universitas Muhammadiyah Ponorogo, Indonesia.

E-Mail: suluh.dian@gmail.com 